\title{
Thirty-first award of the Florence Nightingale Medal
}

Geneva, 12 May 1987

Circular No. 546

To the Central Committees of National Red Cross and Red Crescent Societies

LAdies ANd GentLEMEN,

In its Circular No. 537 of 25 August 1986 the International Committee of the Red Cross had invited the Central Committees of National Societies to send in the names of nurses and voluntary aids who are active members or regular helpers of a National Society or of an affiliated medical or nursing institution whom they judged qualified to receive the Florence Nightingale Medal.

The object of this Medal is to honour nurses and voluntary aids who have distinguished themselves in time of peace or war by their exceptional courage and devotion to wounded, sick or disabled persons or those whose health is threatened.

The International Committee, after a careful study of the candidatures submitted by National Societies, has the pleasure of announcing that for the thirty-first distribution the Medal has been awarded to the following nurses and voluntary aids. Since the designation, qualification and duties of nursing personnel do not always have an exact equivalent in the various languages, it seemed to be preferable to leave them as indicated by each Society. 


\section{Australie - Australia}

1. Sister Berenice Nonie Ryan. Graduate Nurse; Assistant Director of Nursing, Projects and Research, Dandenong and District Hospital, Dandenong.

2. Mrs. Elizabeth Eleanor Nissen. Voluntary Aid; Vice-Chairman, Victorian Division, Melbourne.

\section{CANADA}

3. Mrs. Barbara Ann Robinson. Graduate Nurse; General Duty Nurse, Medical Unit, Hospital, Middleton; Instructor/Trainer and Instructor Red Cross Fun and Fitness.

4. Mrs. Jane Bryant Lehman. Graduate Nurse; Registered Nurse; Volunteer Nurse, Indian Reserve, Anahim Lake; Health Service to Native Indian Communities in Rural Isolated Areas Around Anahim.

Medal awarded posthumously.

5. Ms. Cécile Emilia Grenier, R.N. Graduate Nurse; ICRC medical relief missions; League disaster relief missions.

République Populaire de Chine - The People's Republic of China - República Popular de China

6. Mrs. Shi Mei Li. Graduate Nurse; Senior Nurse, Shanghai.

7. Miss Zhang Yun-qing. Graduate Nurse; Vice-Head Nurse of Laoning Tumour Hospital, Shenyang.

8. Miss Chen Lu-de. Graduate Nurse; Adviser to the First Affiliated Hospital of Tianjin Medical College; Member of the Standing Committee of the Chinese Nursing Association; Chairman of the Tianjin Branch of the Chinese Nursing Association.

République de Corée - Republic of Korea - Republica de COREA

9. Mrs. Keumja Choi. Graduate Nurse; Registered Nurse; Director of Nursing, Sorokdo National Leprosarium, Junnam. 
10. Mrs. Aehyong Cho. Graduate Nurse; Registered Nurse; Director of Nursing, Sodaemun City Hospital, Seoul.

11. Mrs. Soonku Kong. Graduate Nurse; Registered Nurse; Part-time clinical lecturer; Director of Nursing, Chonju Presbyterian Medical Centre, Chonju.

\section{Costa Rica}

12. Sra. Orfilia Blanco Loáiciga. Enfermera diplomada; enfermera jefa Centro de Salud, Ciudad Quesada, San Carlos y jefa de enfermeras voluntarias del comité cantonal de la Cruz Roja en San Carlos.

CuBA

13. Srta. Maria Noelia Sánchez Martínez. Enfermera diplomada; enfermera especializada, La Habana.

14. Srta. Amada Izquierdo Hernández. Enfermera diplomada; enfermera especializada, La Habana.

Republique arabe d'Egypte - Arab Republic of Egypt - RepúbLICA Árabe de EGIPTo

15. Mrs. Aleya El Far. Red Crescent Volontary Aid; Member of the Board of the Egyptian Red Crescent and Treasurer of the Cairo branch.

Etats-Unis d'AmÉRique - United States of America - Estados UNIDOS DE AMÉRICA

16. Mrs. Ruthelle Duke Wilson. Graduate Nurse; Volunteer Nursing Chairman, De Soto, Texas; Disaster Nursing Consultant, Dallas County Chapter; Health Services Consultant Territories 6 and 8; National Disaster Reserve Nurse; Nurse Supervisor, Children's Medical Center, Dallas, Texas.

ETHIOPIE - ETHIOPIA - ETIOPÍA

17. Sister Legesse Zenebework. Graduate Nurse; Instructor in Health Assistant School. 
18. Sister Ayana Aster. Graduate Nurse; Matron in Urael M.C.H. Clinic and Health Centre.

19. Sister Kebede Berkinesh. Graduate Nurse; Matron M.C.H. Clinic of Bata.

Finlande - Finland - Finlandia

20. Miss Ingrid Margaretha Hämelin. Graduate Nurse; Honorary Fellow, Royal College of Nursing of the United Kingdom; former Planning Officer, Helsinki City Health Department; retired.

France - Francia

21. $M^{\text {lle }}$ Rose-May Barthomivat de la Besse. Infirmière diplômée; infirmière en milieu scolaire, infirmière volontaire à la Croix-Rouge française.

22. M $M^{\text {lle }}$ Hélène Escoffier. Diplôme simple d'infirmière; diplôme d'assistante sociale; retraitée; membre bénévole du groupe de recherches historiques de la Croix-Rouge française.

23. $M^{m e}$ Danielle Elisabeth Savina. Diplôme d'Etat d'infirmière; mission CICR en Angola; supervision des équipes soins infirmiers et nutritionnels; enseignement personnel médical local.

24. $M^{m e}$ Georgette Terray. Diplôme d'Etat d'infirmière; présidente du comité local Croix-Rouge française de Ris Orangis.

Grande-Bret

25. Miss Phyllis Eileen Edwards RGN SCM HV. Graduate Nurse; Medical relief missions in Nepal with Save the Children Fund and in Uganda with the ICRC.

Medal awarded posthumously.

26. Mrs. Annette Kerr RGN. Graduate Nurse; Work on feeding programmes, with OXFAM in Somalia and with the UNHCR in the Cameroons; Medical Mission with the ICRC, Peshawar Hospital (Pakistan); Medical Practice Nursing Sister. 
HONGRIE - HuNGARY - HUNGRíA

27. $M^{\text {me }}$ Jánosné Harmati. Infirmière diplômée, volontaire de la CroixRouge hongroise, retraitée.

$$
\text { ITALIE - ITALY - ITALIA }
$$

28. $M^{\text {me }}$ Luigia Faccaro Marocco. Infirmière volontaire; inspectrice nationale des Infirmières volontaires de la Croix-Rouge italienne.

29. $M^{\text {lle }}$ Maria Rita Orzalesi. Infirmière volontaire.

$$
\text { JAPON - JAPAN - JAPÓN }
$$

30. Miss Yasuko Otake. Nurse and Midwife State Diploma; Professor at the Japanese Red Cross Musashino Women's Junior College of Nursing.

31. Miss Shizui Sakumoto. Graduate Nurse; Registered Nurse; Retired.

32. Miss Katsu Hayakawa. Graduate Nurse; Registered Nurse; Member of the Board of Directors, the Aino Educational Institute.

$$
\text { Liban - Lebanon - Líbano }
$$

33. $M^{\text {me }}$ Hoda Asmar. Infirmière diplômée; membre du Comité Central, responsable de la section des soins infirmiers.

Nouvelle-Zélande - New Zealand - Nueva Zelandia

34. Ms Glenys Lorraine Rodger-Checchi. Graduate Nurse; Registered Midwife; From 1980 to 1986 seconded to ICRC operations in Asia and Africa.

\section{OUGANDA - UGANDA}

35. Miss Catherine Musoke. Registered Nurse; Volunteer of the Uganda Red Cross.

Medal awarded posthumously. 
Pologne - Poland - Polonia

36. $M^{\text {me }}$ Irena Romanowska. Infirmière diplômée; retraitée.

37. $M^{\text {me }}$ Helena Rabowska-Witkiewicz. Infirmière diplômée; retraitée; travail à mi-temps à l'Hôpital (Varsovie) et travail social à l'Association Polonaise des Infirmières.

38. $M^{\text {me }}$ Waleria Peksa. Infirmière diplômée; retraitée.

39. $M^{\text {me }}$ Magdalena Puslowska-Owczarek. Infirmière diplômée; retraitée.

République démocratique allemande - German Democratic Republic - República Democrática Alemana

40. Mrs. Maria Elisabeth Seipolt. State Diploma in Nursing; Retired; Member of the Presidency and of the Bureau of the Presidency of the German Red Cross of the German Democratic Republic; Social worker in care of tumour patients.

Tchécoslovaquie - Czechoslovakia - Checoslovaquia

41. Mrs. Marie Soprova. Volontary Aid; Retired.

Thaïlande - Thailand - Tailandia

42. Mrs. Nongyao Chotpanich. Graduate Nurse; Director of Nursing, Chulalongkorn Hospital, Thai Red Cross Society.

43. Mrs. Oravonna Utaisen. Graduate Nurse; Director, College of Nursing, Thai Red Cross Society.

U.R.S.S. - U.S.S.R.

44. $M^{\text {me }}$ Maria $P$. Signekova. Infirmière diplômée; infirmière de l'hôpital $\mathrm{du}$ village Toktogoul, région de Tallass, Kirghizie.

45. $M^{\text {me }}$ Antonina A. Pikhteeva. Infirmière diplômée; infirmière du service de la santé de l'usine de coton, K-Kourgan, région de Samarcande, Ouzbékie.

46. $M^{\text {me }}$ Vera $V$. Shirokaia. Infirmière diplômée; infirmière à l'hôpital N I de Tsélinograde, Kazakhie. 
With the thirty-first award on 12 May 1987, a total of 973 medals have been awarded.

The medals and diplomas, accompanied in each case by a photogravure reproduction of the portrait of Florence Nightingale, will be sent as quickly as possible to the Central Committees. The International Committee of the Red Cross would like to receive acknowledgement of their receipt in due course.

The Committee would be grateful if the Medals could be presented in the course of this year and requests the Central Committees to invest the presentation ceremony with a character of formality in keeping with the founders' wishes.

FOR THE INTERNATIONAL COMMITTEE OF THE RED CROSS

\section{Cornelio SOMMARUGA}

President 